\title{
Luffa aegyptiaca (Gourd) Fruit Juice as a Source of Peroxidase
}

\author{
R. S. S. Yadav, ${ }^{1}$ K. S. Yadav, ${ }^{1}$ and H. S. Yadav $^{2}$ \\ ${ }^{1}$ Department of Chemistry, D.D.U. Gorakhpur University, Gorakhpur 273 009, India \\ ${ }^{2}$ Department of Chemistry, NERIST, Nirjuli, 791109, India
}

Correspondence should be addressed to R.S.S. Yadav, rssy_chemistry@rediffmail.com

Received 17 December 2010; Revised 1 March 2011; Accepted 18 May 2011

Academic Editor: Jorgen Andreaus

Copyright ( 2011 R. S. S. Yadav et al. This is an open access article distributed under the Creative Commons Attribution License, which permits unrestricted use, distribution, and reproduction in any medium, provided the original work is properly cited.

\begin{abstract}
Peroxidases have turned out to be potential biocatalyst for a variety of organic reactions. The research work reported in this communication was done with the objective of finding a convenient rich source of peroxidase which could be used as a biocatalyst for organic synthetic reactions. The studies made have shown that Luffa aegyptiaca (gourd) fruit juice contains peroxidase activity of the order of 180 enzyme unit $/ \mathrm{mL}$. The $K_{m}$ values of this peroxidase for the substrates guaiacol and hydrogen peroxide were 2.0 and $0.2 \mathrm{mM}$, respectively. The $\mathrm{pH}$ and temperature optima were 6.5 and $60^{\circ} \mathrm{C}$, respectively. Like other peroxidases, it followed double displacement type mechanism. Sodium azide inhibited the enzyme competitively with $K_{i}$ value of $3.35 \mathrm{mM}$.
\end{abstract}

\section{Introduction}

Peroxidase (E.C. 1.11.1.7) is a heme-containing enzyme, which catalyses the oxidation of a wide variety of organic and inorganic substrates using hydrogen peroxide as the electron acceptor $[1,2]$. Peroxidases are widely distributed in living organisms including microorganisms, plants, and animals [3]. It is mainly located in the cell wall [4], and it is one of the key enzymes controlling plant growth and development. It is involved in various cellular processes including construction, rigidification, and eventual lignifications of cell walls [5], suberization [6], organogenesis [7], phenol oxidation [8], crosslinking of cell wall proteins [9], and protection of tissue from damage and infection by pathogenic microorganisms [10-12]. It is also used in clinical diagnosis and microanalytical immunoassays because of its high sensitivity. Apart from these applications, peroxidases have been used for biotransformations in organic synthesis [13].

Recent studies have revealed that not all peroxidases are similar in their structures and functions [14-21]. Lignin peroxidase differs from horseradish peroxidase in the sense that lignin peroxidase directly oxidizes veratryl alcohol whereas horseradish peroxidase cannot [17]. Soyabean peroxidase [17] has lignin peroxidase type activity, but it is more stable at acidic $\mathrm{pH}$ and at higher temperatures than the lignin peroxidase. During last decades, peroxidases have turned out to be potential biocatalysts [22] for variety of organic reactions, for example, enantioselective reduction of hydroperoxides [23], hydroxylation of arenes [24], epoxidation of olefins [20], halogenation [25], N-oxidation [26], and sulfoxidation [27]. The studies reported in this communication were performed with the objective of finding a convenient rich source of peroxidase which could be tested for the above organic biotransformations. We have found that aegyptiaca fruit juice is a novel good source of peroxidase. The enzymatic properties of peroxidase of L. aegyptiaca fruit juice have been reported in this communication.

\section{Materials and Methods}

2.1. Chemicals. Guaiacol was from Sigma Chemical Company, St. Louis USA. All other chemicals used in these investigations were either from Himedia Laboratory Ltd, Mumbai or from E. Merck (India) Ltd., Mumbai, and were used without further purifications.

2.2. Isolation of the Enzyme. The enzyme was isolated by cutting the L. aegyptiaca fruit into the small pieces, crushing the pieces in mortar with pestle, and extracting the juice by keeping the pieces in four layers of cheese cloth and squeezing it. The juice was centrifuged using Sigma (Germany) model 3 K-30 refrigerated centrifuge at $4000 \mathrm{~g}$ for $20 \mathrm{~min}$ at $4^{\circ} \mathrm{C}$ to remove the cloudiness of the juice. The clear juice was 
stored at $4^{\circ} \mathrm{C}$. The enzyme stored in this way has reasonable activity even after 3 months.

2.3. Peroxidase Activity Assay. Peroxidase activity of the enzyme was measured in $1 \mathrm{~mL}$ reaction solution containing $50 \mathrm{mM}$ sodium phosphate buffer $\mathrm{pH} 7.0$ at $30^{\circ} \mathrm{C}$ using $5 \mathrm{mM}$ guaiacol, $0.6 \mathrm{mM}$ hydrogen peroxide as the substrates and by monitoring the absorbance changes at $\lambda=470 \mathrm{~nm}$ using molar extinction coefficient value of $2.66 \times 10^{4} \mathrm{M}^{-1} \mathrm{~cm}^{-1}$ for the product tetraguaiacol formed by the enzymatic reaction $[28,29]$. The reaction solution was allowed for thermal equilibration for 10 minutes, $10 \mu \mathrm{L}$ of the enzyme stock $180 \mathrm{IU} / \mathrm{mL}$ was added, and activity measurement was started immediately and was continued for 180 seconds. All spectrophotometric measurements were done with UV/Vis spectrophotometer Hitachi (Japan) model U-2000 which was fitted with electronic temperature control unit for variation of temperature in the cuvettes. The least count of the absorbance measurement was 0.001 , and one enzyme unit is the amount of enzyme which produces $1 \mu \mathrm{mol} / \mathrm{min}$ of the product.

2.4. Kinetic Studies. The steady state kinetics of the enzyme was studied using guaiacol and $\mathrm{H}_{2} \mathrm{O}_{2}$ as the variable substrates and monitoring the steady state formation of tetraguaiacol as mentioned in the assay section. While varying the concentration of guaiacol, the concentration of $\mathrm{H}_{2} \mathrm{O}_{2}$ was fixed at enzyme saturating value $0.6 \mathrm{mM}$. Similarly, while varying the concentration of $\mathrm{H}_{2} \mathrm{O}_{2}$, the concentration of guaiacol was fixed at the enzyme saturating value $5 \mathrm{mM}$. The $K_{m}$ values were calculated using linear regression analysis of the data points of double-reciprocal plots. Each point of steady state velocity was an average of triplicate measurements, and the percentage standard deviation was less than $5 \%$.

The $\mathrm{pH}$ optimum was determined by measuring the relative activity of the enzyme in the $\mathrm{pH}$ range 2.5-9.0 using buffer prepared with $\mathrm{H}_{3} \mathrm{PO}_{4} / \mathrm{NaH}_{2} \mathrm{PO}_{4} / \mathrm{Na}_{2} \mathrm{HPO}_{4}$. The composition of the reaction solution was the same as mentioned in the peroxidase activity assay. The temperature optimum was determined by measuring the relative activity of the enzyme in the temperature range $20-80^{\circ} \mathrm{C}$ at fixed $\mathrm{pH} 7.0$ and using the reaction solution of the composition mentioned in peroxidase activity assay. Before each measurement, the reaction mixture in the spectrophotometer cuvette was allowed for $10 \mathrm{~min}$ for temperature equilibration, the reaction was initiated by the addition of $10 \mu \mathrm{L}$, of concentrated enzyme stock having $180 \mathrm{IU} / \mathrm{mL}$, and the activity was measured immediately.

2.5. Inhibition Study. The effect of sodium azide on the activity of the enzyme was studied by monitoring the steadystate velocity of the enzyme-catalysed reaction in the presence of varying concentrations of sodium azide $(0-50 \mathrm{mM})$ using $5 \mathrm{mM}$ guaiacol and $0.6 \mathrm{mM} \mathrm{H}_{2} \mathrm{O}_{2}$ in $50 \mathrm{mM} \mathrm{NaH}_{2} \mathrm{PO}_{4}$ / $\mathrm{Na}_{2} \mathrm{HPO}_{4}(\mathrm{pH} 6.5)$ at $30^{\circ} \mathrm{C} .10 \mu \mathrm{L}$ of the enzyme stock of $180 \mathrm{IU} / \mathrm{mL}$ was added in $1 \mathrm{~mL}$ of the assay solution. The inhibition constant was determined by drawing doublereciprocal plots at different concentrations of the inhibitor using guaiacol as the variable substrate and then drawing the secondary plot of the slopes versus the concentrations of the inhibitor.

\section{Results and Discussion}

The increase of absorbance at $\lambda=470 \mathrm{~nm}, \Delta \mathrm{A}_{470}$, due to the conversion of guaiacol to tetraguaiacol with time in a peroxidase assay solution containing $L$. aegyptiaca fruit juice, is given by the equation $\Delta \mathrm{A}_{470}=2.4 \times 10^{-3} t+11.8 \times 10^{-3}$ which has a correlation factor of 0.9982 determined by the linear regression analysis. There is no increase in absorbance at $\lambda=470 \mathrm{~nm}$ in assay solutions containing no enzyme or the denatured enzyme which was obtained by one hour boiling in water. These results indicated that L. aegyptiaca fruit juice contained peroxidase activity. The analysis of the steady state kinetic measurements showed the presence of $180 \mathrm{IU} / \mathrm{mL}$ of peroxidase in the juice. Thus, L. aegyptiaca fruit juice is a rich and convenient source of peroxidase enzyme, and it can be used for various biotransformation reactions.

Figure 1(a) shows the Michaelis-Menten curve using guaiacol as the variable substrate at the saturating concentration of the other substrate, $\mathrm{H}_{2} \mathrm{O}_{2}(0.6 \mathrm{mM})$ for the determination of $K_{m}$ value for guaiacol. The double-reciprocal plot shown in Figure 1(b) is linear having the correlation factor of 0.9729 showing that the enzyme obeyed MichaelisMenten kinetics [30]. The Michaelis-Menten and doublereciprocal plots using hydrogen peroxide as the variable substrate at the fixed enzyme saturating concentration of guaiacol $(5 \mathrm{mM})$ are shown in Figures 2(a) and 2(b), respectively. The correlation factor for the points on the double-reciprocal plot Figure 2(b) is 0.9864. The calculated $K_{m}$ values for guaiacol and hydrogen peroxide were $2.0 \mathrm{mM}$ and $0.2 \mathrm{mM}$, respectively. The corresponding values of $K_{m}$ for horseradish peroxidase [31], Turkish black radish [32], and Solanum melongena fruit juice [29] were $0.8 \mathrm{mM}$ and $0.1 \mathrm{mM}, 36.0 \mu \mathrm{M}$, and $8.4 \mu \mathrm{M}$, and $6.5 \mathrm{mM}$ and $0.33 \mathrm{mM}$, respectively. The reported enzyme has lower affinity for both the substrates than the peroxidases of horseradish peroxidase and Turkish black radish (Raphanus sativus L.) but higher affinity for both the substrates as compared to the peroxidase of $S$. melongena fruit juice.

Since peroxidases are known to follow double displacement type kinetics [33], L. aegyptiaca fruit juice peroxidase was also analysed for this type of kinetics by measuring the steady state velocity of the enzyme-catalysed reaction at three different fixed concentrations of the hydrogen peroxide and varying the concentration of guaiacol at each hydrogen peroxide concentration and also at three different fixed concentrations of guaiacol and varying the concentration of hydrogen peroxide. Double reciprocal plots (not shown here) in both cases have been found to be parallel straight lines confirming that the reported peroxidase also follows double displacement type mechanism observed in case of other peroxidases [33].

In order to use the reported peroxidase under optimal conditions of $\mathrm{pH}$ and temperature, the dependence of the enzyme activities on the $\mathrm{pH}$ and temperature of the reaction 


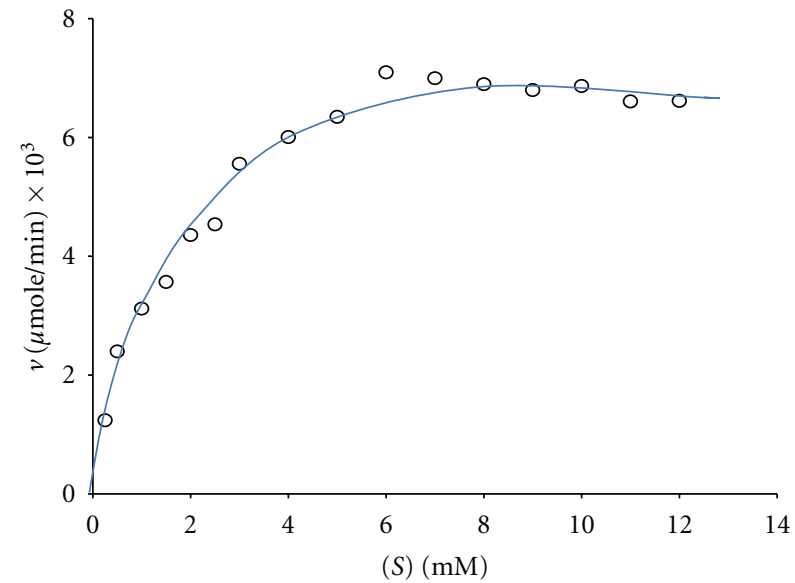

(a)

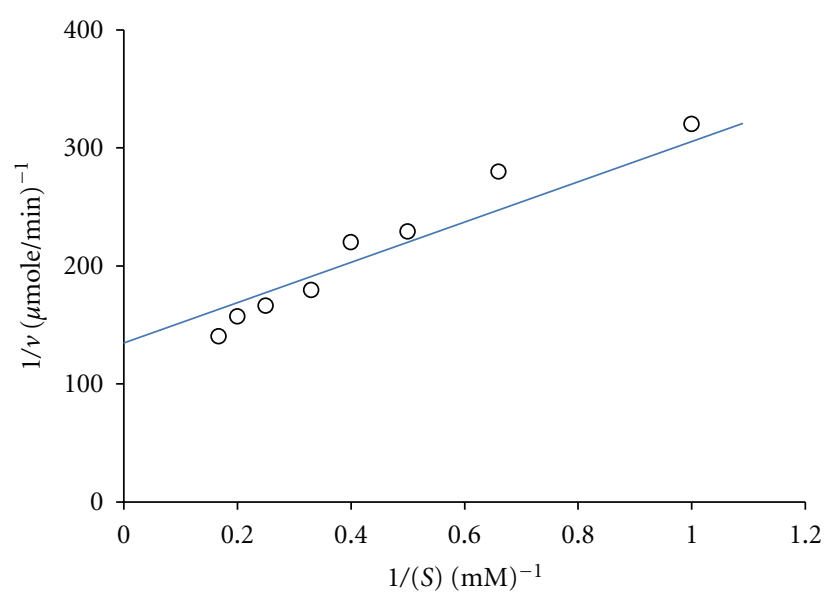

(b)

Figure 1: (a) Michaelis-Menten and (b) double-reciprocal plots for the peroxidase using guaiacol as the variable substrate.

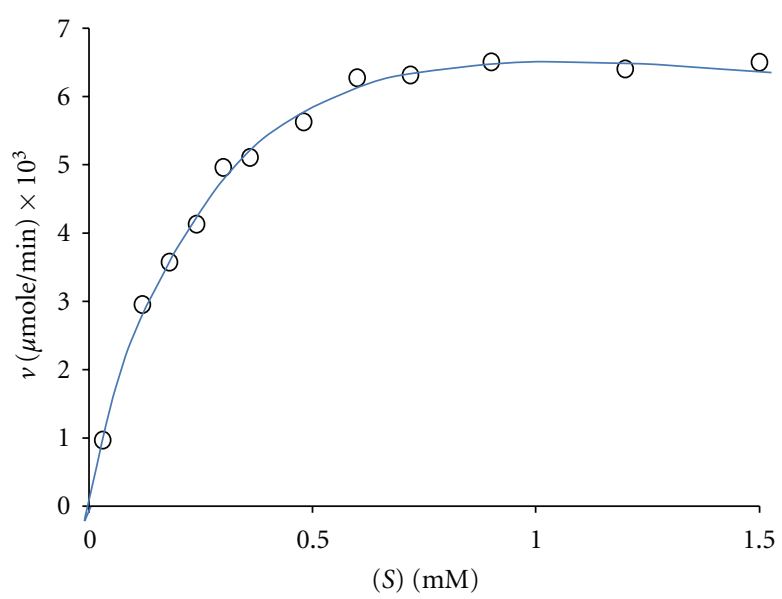

(a)

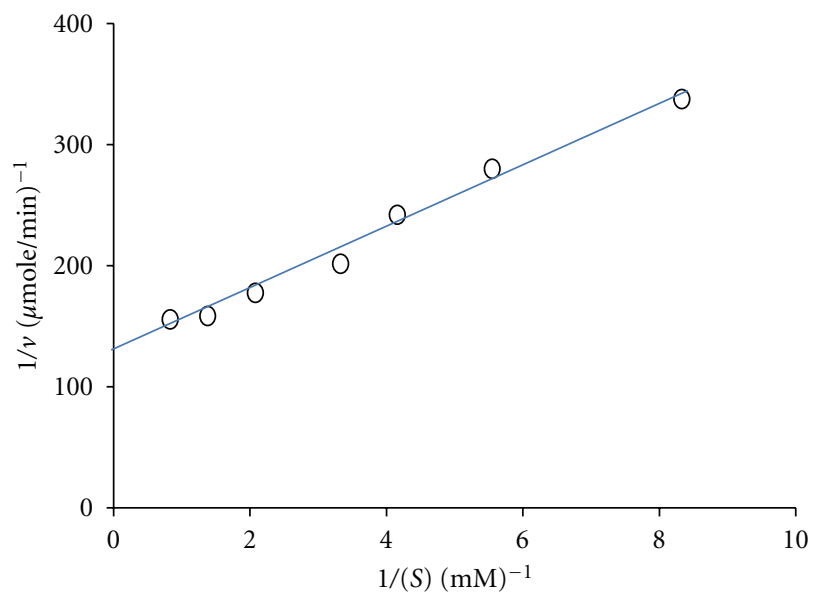

(b)

Figure 2: (a) Michaelis-Menten and (b) double-reciprocal plots for the peroxidase using hydrogen peroxide as the variable substrate.

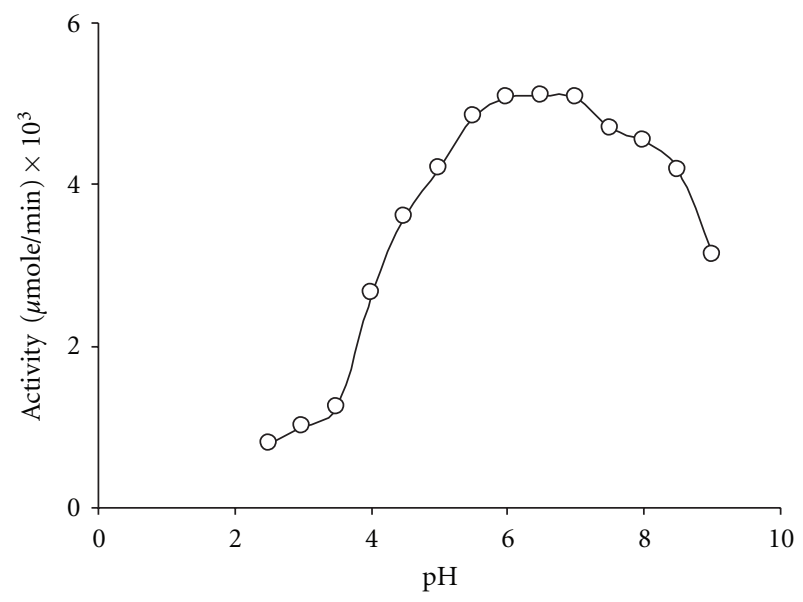

FIGURE 3: Dependence of the enzyme activity on $\mathrm{pH}$ of the assay solution at fixed temperature $30^{\circ} \mathrm{C}$. solutions were studied. The results are shown in Figures 3 and 4 , respectively. The enzyme had $\mathrm{pH}$ optimum at 6.5 and showed more than half of the maximum activity in the $\mathrm{pH}$ range 4.0 to 9.5. Plant peroxidases of $S$. melongena fruit juice [29] and Musa paradisiaca stem juice [34] have been studied in our laboratory. The $\mathrm{pH}$ optima of the peroxidases from these sources have been found to be 5.5 and $4.5 \mathrm{pH}$ units, respectively. Thus the reported peroxidase can be used effectively near neutral $\mathrm{pH}$, whereas the other two peroxidases have $\mathrm{pH}$ optima in more acidic regions.

The temperature optimum of the reported enzyme is $60^{\circ} \mathrm{C}$ calculated from Figure 4 . The temperature optima of the peroxidases from S. melongena fruit juice [29] and $M$. paradisiacal stem juice [34], the other two plant peroxidases reported from our laboratory, were $84^{\circ} \mathrm{C}$ and $62.5^{\circ} \mathrm{C}$ respectively. Thus the peroxidase from L. aegyptiaca fruit juice has the temperature optimum on the higher temperature side as 


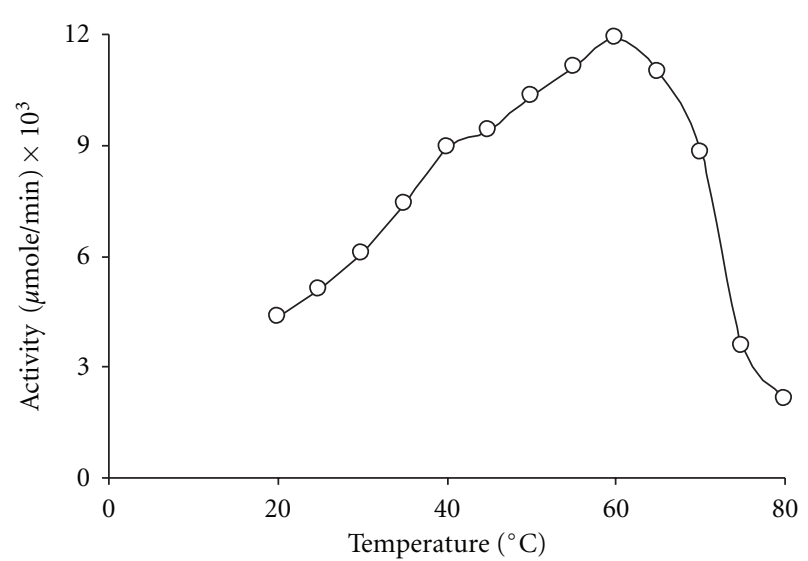

FIGURE 4: Dependence of the enzyme activity on temperature of the assay solution at fixed $\mathrm{pH}$ 7.0.

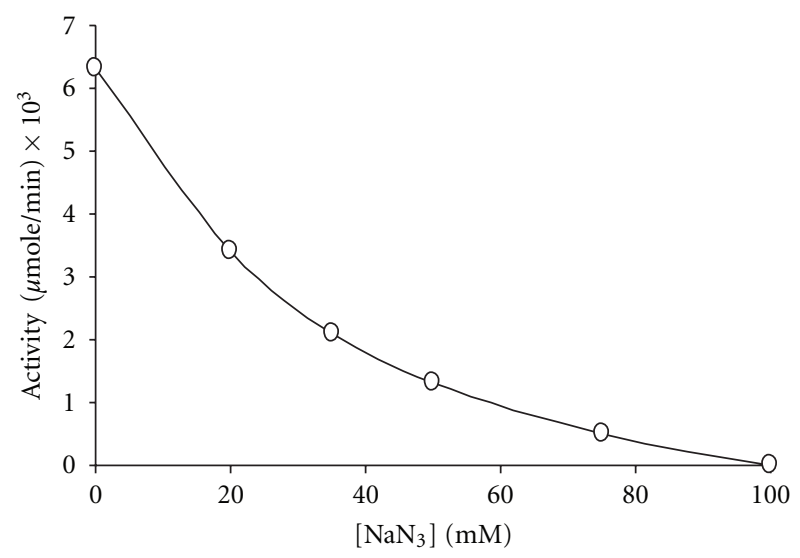

FIGURE 5: Inhibition of the activity of the peroxidase by sodium azide.

in the cases of peroxidases from S. melongena fruit juice [29] and $M$. paradisiacal stem juice [34].

The effect of sodium azide which is known to inhibit peroxidase activity [35] was also studied on the activity of L. aegyptiaca fruit juice peroxidase. The results are shown in Figure 5. The concentration of sodium azide needed to reduce the relative activity of the enzyme to half of its initial value is $20 \mathrm{mM}$. In order to decide the nature of inhibition, double-reciprocal plots were drawn in the presence of different fixed concentrations of sodium azide inhibitor and varying the concentration of guaiacol. The result is shown in Figure 6. The nature of inhibition was competitive, because the intercepts on $y$-axis was independent of the inhibitor concentration. The determined $K_{i}$ value for sodium azide was $3.35 \mathrm{mM}$. The competitive inhibition suggests that the inhibitor competes for the binding of guaiacol substrate to the enzyme [30].

\section{Conclusion}

During the last decades, peroxidases have emerged as good biocatalysts for the variety of organic biotransformation

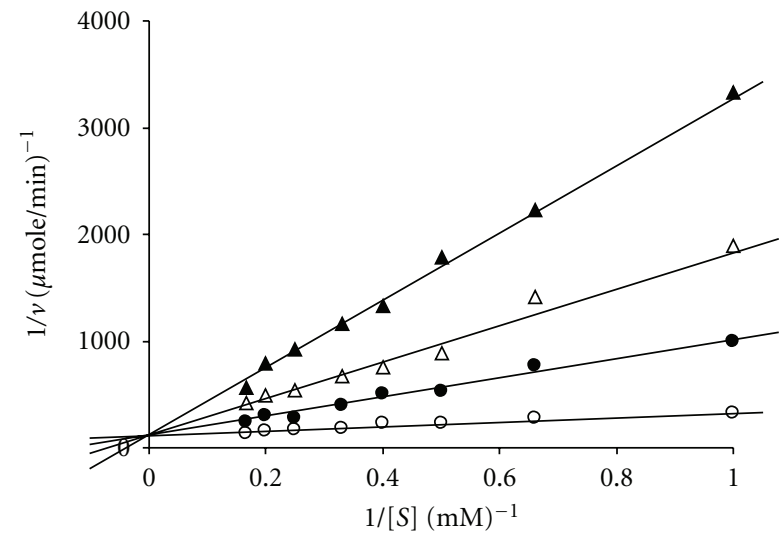

Figure 6: Double-reciprocal plots for peroxidase using guaiacol as the variable substrate at different concentrations of inhibitor sodium azide: $(\bigcirc) 0.0 \mathrm{mM},(\bullet) 20.0 \mathrm{mM},(\triangle) 35 \mathrm{Mm}$, and $(\square) 50 \mathrm{mM}$.

reactions like hydroxylation of arenes, the oxyfunctionalization of phenols and aromatic amines, the epoxidation and halogenation of olefins, the oxygenation of hetero atoms, and the enantioselective reduction of racemic hydroperoxides. This short communication reports a convenient and rich source of a peroxidase which can be used for the above transformations.

\section{Acknowledgment}

R. S. S. Yadav acknowledges the financial support to DST Government of India, New Delhi, in the form of DSTYoung Scientist Fellowship, DO. no. SR/FTP/CS-90/2007, 22.04.2008, under which this research work has been done.

\section{References}

[1] L. Banci, "Structural properties of peroxidases," Journal of Biotechnology, vol. 53, no. 2-3, pp. 253-263, 1997.

[2] A. Yemenicioglu, M. Özkan, and B. Cemeroglu, "Partial purification and thermal characterization of peroxidase from okra (Hibiscus esculentum)," Journal of Agricultural and Food Chemistry, vol. 46, no. 10, pp. 4158-4163, 1998.

[3] J. N. Rodriguez-Lopez, A. T. Smith, and R. N. F. Thorneley, "Recombinant horseradish peroxidase isoenzyme C: the effect of distal haem cavity mutations (His42 $\rightarrow$ Leu and Arg38 $\rightarrow$ Leu) on compound I formation and substrate binding," Journal of Biological Inorganic Chemistry, vol. 1, no. 2, pp. 136142, 1996.

[4] E. L. Chen, Y. A. Chen, L. M. Chen, and Z. H. Liu, "Effect of copper on peroxidase activity and lignin content in Raphanus sativus," Plant Physiology and Biochemistry, vol. 40, no. 5, pp. 439-444, 2002.

[5] M. Quiroga, C. Guerrero, M. A. Botella et al., "A tomato peroxidase involved in the synthesis of lignin and suberin," Plant Physiology, vol. 122, no. 4, pp. 1119-1127, 2000.

[6] M. A. Bernards, W. D. Fleming, D. B. Llewellyn et al., "Biochemical characterization of the suberization-associated anionic peroxidase of potato," Plant Physiology, vol. 121, no. 1, pp. 135-145, 1999.

[7] D. J. Lee, S. S. Kim, and S. S. Kim, "The regulation of Korean radish cationic peroxidase promoter by a low ratio of 
cytokinin to auxin," Plant Science, vol. 162, no. 3, pp. 345-353, 2002.

[8] L. M. Lagrimini, "Wound-induced deposition of polyphenols in transgenic plants overexpressing peroxidase," Plant Physiology, vol. 96, no. 2, pp. 577-583, 1991.

[9] L. S. Schnabelrauch, M. Kieliszewski, B. L. Upham, H. Alizedeh, and D. T. A. Lamport, "Isolation of pl 4.6 extensin peroxidase from tomato cell suspension cultures and identification of Val-Tyr-Lys as putative intermolecular cross-link site," Plant Journal, vol. 9, no. 4, pp. 477-489, 1996.

[10] I. Y. Sakharov, J. L. Castillo, J. C. Areza, and I. Y. Galaev, "Purification and stability of peroxidase of African oil palm Elaies guineensis," Bioseparation, vol. 9, no. 3, pp. 125-132, 2000.

[11] I. Gülçin and A. Yildirim, "Purification and characterization of peroxidase from Brassica oleracea var. Acephala," Asian Journal of Chemistry, vol. 17, no. 4, pp. 2175-2183, 2005.

[12] I. G. Şat, "The effect of heavy metals on peroxidase from Jerusalem artichoke (Helianthus tuberosus L.) tubers," African Journal of Biotechnology, vol. 7, no. 13, pp. 2248-2253, 2008.

[13] W. Adam, M. Lazarus, C. R. Saha-Möller et al., "Biotransformations with peroxidases," Advances in Biochemical Engineering and Biotechnology, vol. 63, pp. 73-108, 1999.

[14] I. G. Gazarian, L. M. Lagrimini, S. J. George, and R. N. F. Thorneley, "Anionic tobacco peroxidase is active at extremely low $\mathrm{pH}$ : veratryl alcohol oxidation with a $\mathrm{pH}$ optimum of 1.8," Biochemical Journal, vol. 320, no. 2, pp. 369-372, 1996.

[15] M. Kvaratskhelia, C. Winkel, and R. N. F. Thorneley, "Purification and characterization of a novel class III peroxidase isoenzyme from tea leaves," Plant Physiology, vol. 114, no. 4, pp. 1237-1245, 1997.

[16] I. G. Gazaryan and L. M. Lagrimini, "Purification and unusual kinetic properties of a tobacco anionic peroxidase," Phytochemistry, vol. 41, no. 4, pp. 1029-1034, 1996.

[17] J. P. Mc Eldoon, A. R. Pokora, and J. S. Dordick, "Lignin peroxidase-type activity of soybean peroxidase," Enzyme and Microbial Technology, vol. 17, no. 4, pp. 359-365, 1995.

[18] B. C. Finzel, T. L. Poulos, and J. Kraut, "Crystal structure of yeast cytochrome c peroxidase refined at $1.7 \AA$ resolution," Journal of Biological Chemistry, vol. 259, no. 21, pp. 1302713036, 1984.

[19] T. L. Poulos, S. L. Edwards, H. Wariishi, and M. H. Gold, "Crystallographic refinement of lignin peroxidase at $2 \AA$," Journal of Biological Chemistry, vol. 268, no. 6, pp. 4429-4440, 1993.

[20] M. Sundaramoorthy, K. Kishi, M. H. Gold, and T. L. Poulos, "The crystal structure of manganese peroxidase from Phanerochaete chrysosporium at $2.06 \AA$ resolution," Journal of Biological Chemistry, vol. 269, no. 52, pp. 32759-32767, 1994.

[21] W. R. Patterson and T. L. Poulos, "Crystal structure of recombinant pea cytosolic ascorbate peroxidase," Biochemistry, vol. 34, no. 13, pp. 4331-4341, 1995.

[22] R. Noyori, Asymmetric Catalysis in Organic Synthesis, Willy Inter Science, New York, NY, USA, 1994.

[23] R. Akasaka, T. Mashino, and M. Hirobe, "Hydroxylation of benzene by horseradish peroxidase and immobilized horseradish peroxide in an organic solvent," Bioorganic and Medicinal Chemistry Letters, vol. 5, no. 16, pp. 1861-1864, 1995.

[24] E. N. Jacobsen, "Asymmetric catalytic epoxidation of unfunctionalized olefins," in Catalytic Asymmetric Synthesis, I. Ojima, Ed., p. 159, VCH, Weinheim, Germany, 1993.
[25] M. Hofrichter and R. Ullrich, "Heme-thiolate haloperoxidases: versatile biocatalysts with biotechnological and environmental significance," Applied Microbiology and Biotechnology, vol. 71, no. 3, pp. 276-288, 2006.

[26] P. Yadav, J. K. Sharma, V. K. Singh, and K. D. S. Yadav, "Noxidation of arylamines to nitrosobenzenes using chloroperoxidase purified from Musa paradisiaca stem juice," Biocatalysis and Biotransformation, vol. 28, no. 3, pp. 222-226, 2010.

[27] S. Colonna, N. Gaggereo, G. Carrea, and P. Pasta, "The microperoxidase-11 catalyzed oxidation of sulfides is enantioselective," Tetrahedron Letters, vol. 35, no. 48, pp. 91039104, 1994.

[28] J. R. Whitaker, Principles of Enzymology for Food Sciences, Marcel Dekker, New York, NY, USA, 1972.

[29] S. K. Vernwal, R. S. S. Yadav, and K. D. S. Yadav, “Musa paradisiaca stem juice as a source of peroxidase and lignin peroxidase," Indian Journal of Experimental Biology, vol. 38, no. 10, pp. 1036-1040, 2000.

[30] P. C. Engel, Enzyme Kinetics: The Steady State Approach, Chapman and Hall, London, UK, 1977.

[31] J. N. Rodriguez-Lopez, A. T. Smith, and R. N. F. Thorneley, "Role of arginine 38 in horseradish peroxidase: a critical residue for substrate binding and catalysis," Journal of Biological Chemistry, vol. 271, no. 8, pp. 4023-4030, 1996.

[32] M. Sisecioglu, I. Gülcin, M. Cankaya et al., "Purification and characterization of peroxidase from turkish black radish (Raphanus sativus L.)," Journal of Medicine and Plants Resources, vol. 4, pp. 1187-1196, 2010.

[33] M. Tien and T. K. Kirk, "Lignin-degrading enzyme from Phanerochaete chrysosporium: purification, characterization and catalytic properties of a unique $\mathrm{H}_{2} \mathrm{O}_{2}$-requiring oxygenase," Proceedings of the National Academy of Sciences of the United States of America, vol. 81, no. 8, pp. 2280-2284, 1984.

[34] S. K. Vernwal, R. S. S. Yadav, and K. D. S. Yadav, “Musa paradisiaca stem juice as a source of peroxidase and ligninperoxidase," Indian Journal of Experimental Biology, vol. 38, no. 10, pp. 1036-1040, 2000.

[35] M. P. J. Van Deurzen, F. van Rantwijk, and R. A. Sheldon, "Selective oxidations catalyzed by peroxidases," Tetrahedron, vol. 53, no. 39, pp. 13183-13220, 1997. 

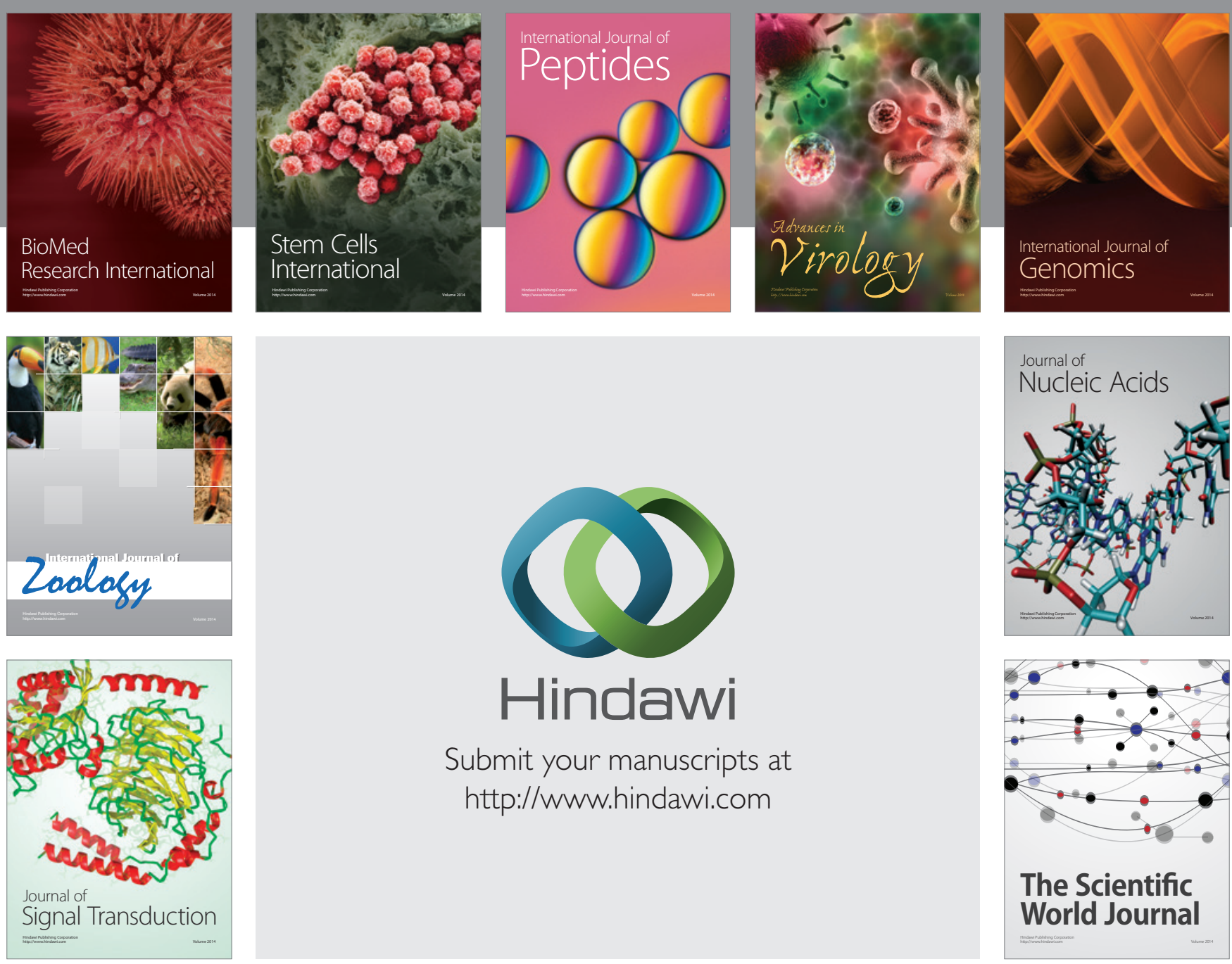

Submit your manuscripts at

http://www.hindawi.com
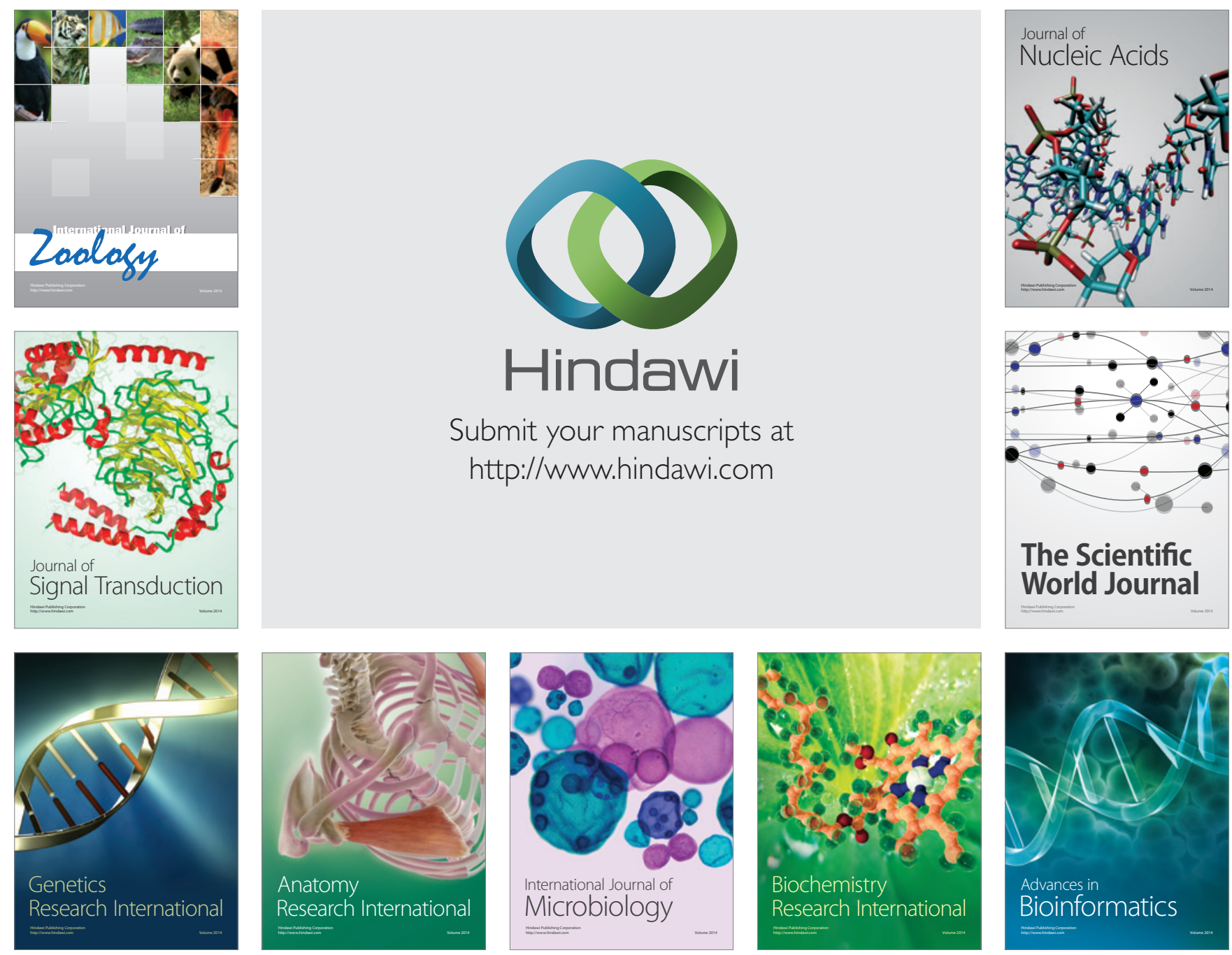

The Scientific World Journal
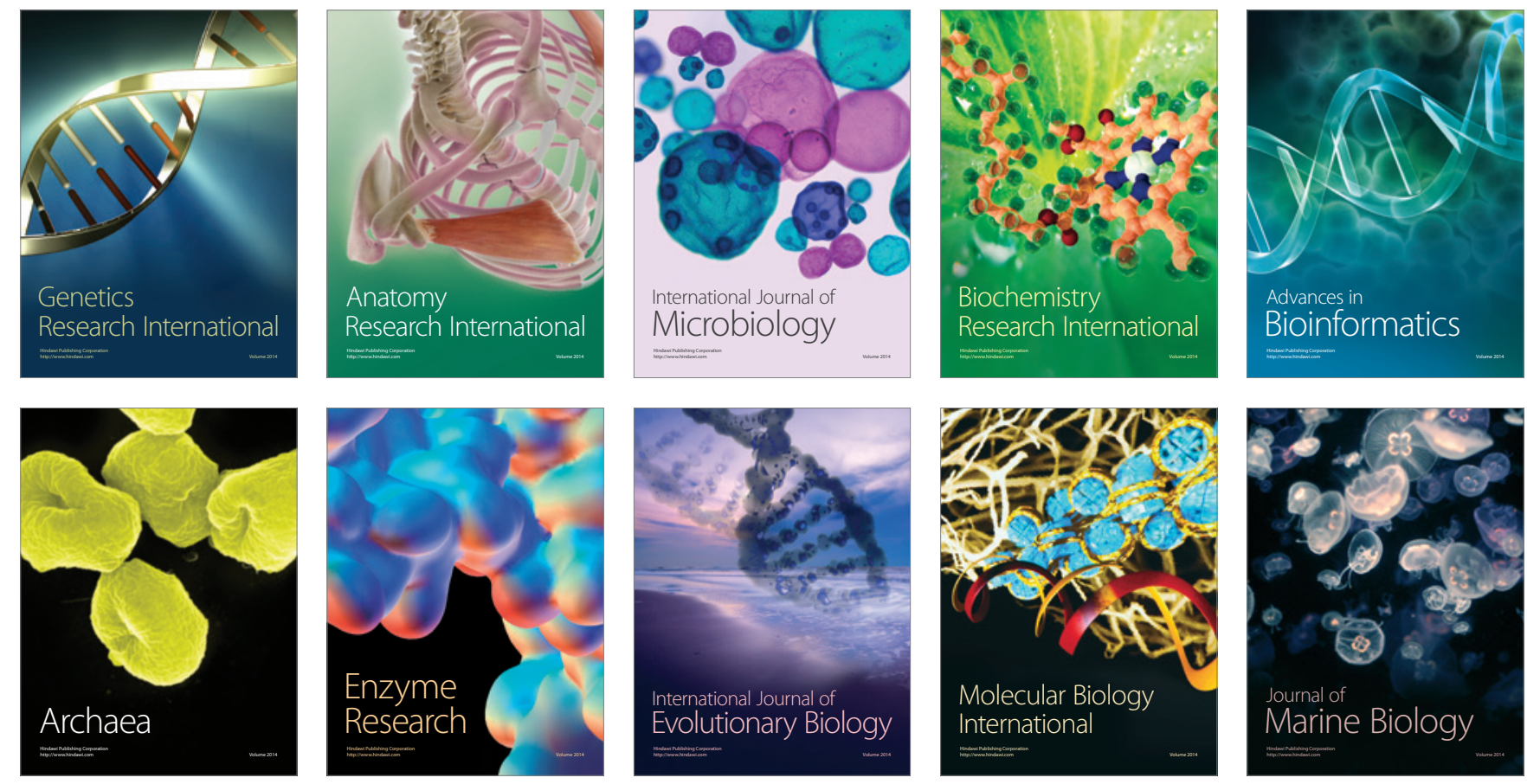